\title{
Hemşirelerin Temel Psikolojik İhtiyaçları ve Etkileyen Faktörler
}

\author{
Basic Psychological Needs of Nurses and Factors Affecting
}

\author{
Hava KAYA ${ }^{\mathrm{a}}$, Özlem ŞAHIN ALTUN ${ }^{\mathrm{b}}$
}

ÖZ Amaç: Bu araştırma; hemşirelerin temel psikolojik ihtiyaçlarını ve etkileyen faktörleri belirlemek amacıyla tanımlayıcı olarak yapılmıştır. Materyal ve Metot: Araştırma, Nisan 2014-Ocak 2015 tarihleri arasında Van ilindeki devlet hastaneleri ve üniversite hastanesinde görev yapan ve araştırmaya katılmayı kabul eden 706 hemşire üzerinde gerçekleştirilmiştir. Araştırmanın verileri "Kişisel Bilgi Formu " ve Temel Psikolojik İhtiyaçlar Ölçeği (TPİÖ) ile toplanmıştır. Verilerin analizi SPSS 20.0 istatistik analiz programı aracılı̆̆ ile sayı, yüzde dăğlımı, ortalama, bağımsız gruplarda t-testi, One Way Anova testi ile Kruskal Wallis testi ile değerlendirilmiştir. Bulgular: Araştırma kapsamına alınan hemşirelerin sosyo-demografik özellikleri incelendiğinde hemşirelerin \%63.3'ünün kadın, \%46.0'sının 26-33 yaş aralığında, \%49.2'sinin lisans mezunu, \%50.7'sinin evli olduğu, \%58.1'inin çocuk sahibi olmadığı, \%41.2'sinin 2 çocuk sahibi olduğu ve \%33.1'inin gelir durumunun kısmen yeterli olduğu, \%53.1'inin toplam çalışma süresinin 1-5 yıl olduğu saptanmıştır. Hemşirelerin TPIÖ toplam puan ortalamalarının $69.61 \pm 8.84$ olduğu bulunmuştur. TPIÖ ölçeği alt boyut ortalamaları ise, özerlik ihtiyacı alt boyutu için $22.61 \pm 4.58$, yeterlilik ihtiyacı alt boyutu için19.91 \pm 3.13 iken, ilişki alt boyutu için ise $27.43 \pm 3.95$ olarak saptanmıştır. Sonuç: Hemşirelerin, temel psikolojik ihtiyaçlarının yüksek düzeyde olduğu belirlenmiştir.

Anahtar Kelimeler: Hemşire, temel psikolojik ihtiyaçlar

ABSTRACT Aim: This study was carried out descriptively to determine the basic psychological needs of nurses and the factors that influence them. Materials and Method: The research was carried out in April-October 2014 on 706 nurses who both work in the state hospitals and in the university hospital in Van and have agreed to participate in the research. The research data was collected by using "Personal Information Form" and "Basic Psychological Needs Scale". The analysis of the data was observed by testing number, percentage, average, t-test in independent groups, One Way ANOVA test and Kruskal-Wallis test via SPSS 20.0 statistical analysis program. Result: After the examination of socio-demographic characteristicof nurses, following findings were revealed: $\% 63.3$ of nurses are women, $\% 46.0$ of nurses are $26-33, \% 49.2$ of nurses are bachelor, $\% 50.7$ of nurses are married, $\% 58.1$ have no child, \%41.2 of nurses have 2 children, $\% 33.1$ of nurses' income are partially sufficient, \%53.1 of nurses' work years are about 1-5 years. TPIO total scores of the nurses were found to be $69.61 \pm 8.84$. The average subscales of TPIO scale for the need of autonomy subscale was about $22.61 \pm 4.58$, the need for qualification subscale was about $19.91 \pm 3.13$ and the need for relationship subscale was about $27.43 \pm 3.95$. Conclusion: It was found that basic psychological needs of the nurses were at a high level.

Keywords: Nurse, basic psychological needs, self-determination theory

\begin{abstract}
Giriş
İnsanların sağlığından sorumlu olan sağlık çalışanlarının temel psikolojik ihtiyaçlarının karşılanması, toplumun esenliği açısından önem arz etmektedir. Sağlık çalışanları arasında önemli bir kesimi oluşturan hemşirelerin; sağlıkla uğraşan diğer meslek gruplarına kıyasla daha çok etkileşim içinde oldukları bilinen bir gerçektir (1).

$\mathrm{Bu}$ bakımdan hemşirelerin işlerini sağlıklı ve daha etkili yapabilmeleri için, bireysel olarak mutluluk düzeylerinin yüksek olması önemlidir.
\end{abstract}

\begin{abstract}
Mutluluk düzeyini yükseltmek ise öncelikle, temel psikolojik ihtiyaçlarının karşılanmışlık düzeylerini ve bu düzeylere etki eden faktörleri belirlemekle mümkündür $(1,3)$.

Psikolojik ihtiyaçlar saygınlık, güven, sevgi, ilişki, ait olma ve başarı ihtiyacıdır (4). Bu ihtiyaçlar bireysel farkl1lıklara rağmen, doğaya ygun psikolojik gereklilikler olan iyi oluş ve gelişim ihtiyaçlarından kaynaklanır. Bu ihtiyaçların karşılanmaması bireyde tatminsizlik
\end{abstract}

Geliş Tarihi/Received: 02-03-2017/ Kabul Tarihi/Accepted:27-02-2018

a Öğr. Gör. Hakkari Üniversitesi, Sağllk Hizmetleri Meslek Yüksekokulu, e-mail:havakaya.26@ outlook.com, ORCID:0000-0002-3497-0545

bYard. Doç. Dr. Atatürk Üniversitesi Hemşirelik Fakültesi, Psikiyatri Hemşireliği ABD,E-mail: oz_sahin@ mynet.com, ORCID: 0000-0001-6727-6480

Atatürk Üniversitesi, Sağlık Bilimleri Enstitüsü,Pisikyatri Hemşireliği ABD., Yüksek Lisans Tezidir. 4-6 Şubat 2015 tarihleri arasında Belçika Antwerp şehrinde düzenlenen "CARE4 - International Scientific Nursing and Midwifery Congress" ne poster bildiri olarak sunulmuştur.

Sorumlu Yazar /Correspondence: Yard. Doç. Dr. Özlem ŞAHIN ALTUN, Atatürk Üniversitesi Hemşirelik Fakültesi, Psikiyatri Hemşireliği AD, e-mail: $\underline{\text { zZ_sahin@mynet.com }}$ 
duygusunun ortaya çıkmasına sebep olur. Bireylerde tatmin edilmemiş gereksinimler farkl11ık gösterebileceğinden, bu gereksinimlerin uyarılma ve tatmin edilme yöntemleri de farklıdır (5). Başkalarından alınan tepkiler ve geribildirimlerin psikolojik ihtiyaçların karşılanmasında büyük rol oynadığı da söylenebilir (6).

İnsan, yaşadığ 1 çevreden etkilenen ve yaşadığı çevreyi de etkileyen sosyal bir varlıktır $(2,7)$.Öz-belirleme kuramı (ÖBK): Ryan ve Deci (2000) tarafından geliştirilen kuram bireyin kendi davranışını başlatmasında ve düzenlemesinde seçim duygusunu yaşamasıdır (8). ÖBK'ya göre, insanlar evrensel nitelikte ve doğuştan gelen üç temel psikolojik ihtiyacı (özerklik, yeterlilik ve ilişki) paylaşırlar $(8,9)$. Bu ihtiyaçlar, sosyal olaylar tarafindan desteklendiği takdirde, insanda doğuştan gelen gelişim eğilimi etkinleşir (9). Bu yönüyle ÖBK, insanın sosyal, bilişsel ve duyuşsal özelliklerini bir çatı altında toplayan, sentez niteliğinde bir kuram olarak değerlendirilebilir (3).

ÖBK'ya göre, temel psikolojik ihtiyaçların tatmin edilmemesi, negatif sonuçlar doğurur (10). Kayg1, depresyon, yapılan işlere karş1 duyulan motivasyon da azalış, bireyin kendine ve çevresine yabancılaşması, negatif sonuçlar arasında gösterilebilir (9). Kendisine ve çevresine yabancılaşan, yaptı̆̆ işe motive olmayan ve yaptığı işten zevk almayan birey depresif duygu ve eğilimler gösterebilir ve çevresiyle de sağl1klı iletişim kuramayabilir $(11,12)$. Bununla beraber birey, mesleğini verimli bir şekilde icra edemeyebilir (13). Bu nedenle sağlı hizmetlerinde verimliliğinin artırılması için hemşirelerin temel psikolojik ihtiyaçlarının karşılanmasını engelleyen faktörlerin de ortadan kaldırılması ve bu ihtiyaçlarının karşılanmasına yönelik çalışmaların desteklenmesi önemlidir (14).

Literatür taramalarında, hemşirelerin temel psikolojik ihtiyaçları ile ilgili bir araştırmaya rastlanmamıştır. Fakat Temel Psikolojik İhtiyaçlar Ölçeği (TPİÖ) kullanılarak değişik alanlarda yapılmış tanımlayıcı birçok araştırmaya ulaşılmiştır $(15,16,17,18,19)$.

\section{Materyal ve Metod \\ Araştırmanın Amacı ve Türü}

$\mathrm{Bu}$ araştırma, hemşirelerin temel psikolojik ihtiyaçlarını ve bunları etkileyen faktörleri belirlemek amaciyla tanımlayıcı nitelikte yapılmıştır.

\section{Araştırmanın Yapıldığı Yer ve Zaman}

Araştırma, Nisan 2014-Ocak 2015 tarihleri arasında gerçekleştirilmiştir. Veriler, Van İlinde bulunan Yüzüncü Y1l Üniversitesi Dursun Odabaşı Tıp Merkezi, Van Bölge Eğitim ve Araştırma Hastanesi, İpekyolu Devlet Hastanesi, Van Ağız ve Diş Sağlığı Merkezinden toplanmıştır.

\section{Araştırmanın Evreni ve Örneklemi}

Araştırmanın evrenini, Yüzüncü Y1l Üniversitesi Dursun Odabaşı Tıp Merkezi (352), Van Bölge Eğitim ve Araştırma Hastanesi (531), İpekyolu Devlet Hastanesi (106), Van Ağız ve Diş Sağlığ1 Merkezinde (12), görev yapan hemşireler oluşturmaktadır $(\mathrm{N}=1001)$. Araştırmada herhangi bir örneklem seçim yöntemi kullanılmamış ve verilerin toplandığ 1 tarihler arasında (y1llık, ücretsiz, hastalık, doğum izni vb.) olmayan ve ulaşılabilen 895 hemşire araştırma kapsamına alınmıştır. $\mathrm{Bu}$ hemşirelerden gönüllü olarak katılmak isteyen 814 hemşireye veri toplama aracı dağıtılmış, ancak 706 hemşire anket formunu tam olarak doldurmuştur.

\section{Verilerin Toplanması}

Veriler, araştırmaci tarafindan veri toplama araçları kullanılarak toplanmıştır. Bu araçlar; "Kişisel Bilgi Formu" ile "Temel Psikolojik İhtiyaçlar Ölçeği”dir.

\section{Veri Toplama Araçları Kişisel Bilgi Formu}

Araştırmacı tarafından hazırlanan bu form, hemşirelerin kişisel ve mesleki özellikleri olan yaş, cinsiyet, eğitim, medeni durumu, çocuk sayısı, çalıştığ1 kurum, hangi klinikte çalıştığ1, hemşirelik görevi, kaç yıldır çalıştığı, kaç yıldır klinikte çalıştığı, mesleğini sevip sevmediği, kurumun beklentilerinizi ne oranda karşıladığ 1 , kurumda duygu ve düşüncelerinizin ne oranda dikkate alındığı, günlük iş yükü, gelir düzeyini belirlemeye yönelik toplam 15 sorudan oluşmaktadır.

\section{Temel Psikolojik İhtiyaçlar Ölçeği (TPIÖ)}

Temel Psikolojik İhtiyaçlar Ölçeği (TPIOÖ), ilk olarak iş ortamındaki temel psikolojik ihtiyaçların karşılanmışlık düzeyini belirlemeye yönelik geliştirilmiş, güvenirlik ve geçerliği test edilmiştir. (Gagné) (20) tarafından 2003 yılında geliştirilen 
TPİÖ, küçük değişikliklerle yaşamın genelindeki temel psikolojik ihtiyaçların karşılanmışlığını ölçmeye yönelik olarak dönüştürülmüsstür. Ölçeğin değişik formları bazı çalışmalarda kullanılmış olup güvenirlik ve geçerliği test edilmiştir. Ölçeğin Cronbach's Alpha değeri 0.87'dir.

Sünbül ve arkadaşları tarafindan(21) 2003 yılında TPİÖ Türkçe 'ye uyarlanırken beşli dereceleme tipi tercih edilmiştir. Bu ölçeğin, her bir maddesi bireyin gereksinim duyduğu alanlarla ilgilidir Ölçeğin Cronbach's Alpha değeri 0.87 'dir.

TPİÖ 21 maddeden oluşmaktadır. Ölçeğin üç alt boyutu vardır. Bireyin, bir boyuta giren maddelerden aldığ1 puanlar toplanarak, her bir birey için 3 alt boyutta ölçek puanı elde edilmektedir. $\mathrm{Bu}$ üç boyut sırasıyla: Özerklik İhtiyacı, Yeterlilik İhtiyacı, İlişki ihtiyaçlarıdır. Düz cümle yapısında ve olumlu ifadeleri içeren ölçek maddeleri; 5=Çok Doğru, 4= Doğru, 3=Biraz Doğru, 2=Doğru Değil, 1=Hiç Doğru Değil şeklinde puanlanmaktadır. Kuramsal olarak her bir madde için puanlama 1 ile 5 arasına değiştiği için ölçeğin özerklik alt boyutundan toplam puan en yüksek 35, en düşük 7'tir. Yeterlilik ihtiyac1 alt boyutunda toplam puan en yüksek 30, en düşük 6'dir. İlişki alt boyutunda toplam puan en yüksek 40 , en düşük 8 'dir. Puan arttıkça birey daha fazla psikolojik ihtiyacının karşılandığını hissetmekte, puan düştükçe psikolojik olarak engellendiği anlaşılmaktadır. Örneğin yeterlilik boyutunda kişinin puanının yüksek olması, kişinin kendini yeterli hissettiği anlamına gelmektedir. Ölçeğin boyutlarına göre madde dağılımları (21).

Özerklik ihtiyacı: Bireyin insanlarla ilişki kurarken kendini güvende hissetme ve sosyal ilişkilerinde diğerlerinden bağımsız olma arzusunu kapsamakta ve 1., 4., 8., 11., 14., 17. ve 20. maddeler olmak üzere toplam 7 maddeden oluşmaktadır.

Yeterlilik ihtiyacı: Bireyin hem yaptığı işlerde hem de istediği sonuçları çıkarmakta kendisini muktedir hissetmesiyle ilgilidir. Bu faktör 3., 5., 10.,13., 15. ve 19. maddeler olmak üzere toplam 6 maddeden oluşmaktadır.
İlişki ihtiyacı: Kişisel ilişkilerle ilgili olarak insanın başka insanlarla düşünce ve duygularını paylaşmasını, çevredeki diğer kişilerle yakın ilişsiler kurulmasını, kurulan bu yakın ilişkilerin tatmin edici olmasını kapsayan bu faktör 2., 6., 7., 9., 12., 16., 18. ve 21. maddeler olmak üzere toplam 8 maddeden oluşmaktadır (22).Ölçeğin 3, $4,7,11,15,16,18,19$ ve 20 . maddeleri olumsuz maddelerdir. $\mathrm{Bu}$ araştırma kapsamında toplanan veriler ile iç tutarlık katsayısı hesaplanmış, tüm ölçek için 0.76, özerklik alt boyutu için 0.74, yeterlilik alt boyutu için 0.68 ve ilişki alt boyutu için 0.71 olarak bulunmuştur.

TPİÖ'nden alınan min-max puanlar ve puan ortalamalarının dağılımı incelendiğinde hemşire-lerin özerklik ihtiyacı alt boyutundan $22.61 \pm 4.58$, yeterlilik ihtiyac1 alt boyutundan $19.91 \pm 3.13$, ilişki ihtiyacı alt boyutundan $27.43 \pm 3.95$ puan aldığ1 ve toplam puan ortalamasının ise $69.61 \pm 8.84$ olduğu saptanmıştır.

\section{Verilerin Değerlendirilmesi}

Araştırmadan elde edilen veriler, SPSS 20 istatistik paket programı ile değerlendirilmiştir. Verilerin değerlendirilmesinde Cronbach Alfa Katsayısı, frekans ve yüzde dağglımı, tanımlayıcı istatistikler, bağımsız gruplarda t-testi, One Way Anova Kruskal Wallis önemlilik testi kullanılmıştır.

\section{Araştırmanın Etik İlkeleri}

Araştırmada kullanılması düşünülen ölçek, ölçeği geliştiren kişi tarafindan e-posta yoluyla izini alınmıştır. Araştırmaya başlamadan önce Atatürk Üniversitesi Sağlık Bilimleri Fakültesi Etik Kurul Onay1, say1: 54355720-300/1931 07.05.2017 tarihinde verilerin toplanmasindan önce de araştırmanın yapılacağı kurumlardan yazılı izinler alınmıştır. Veri toplama aşamasında hemşireler, araştırma konusunda bilgilendirilerek sözlü onayları alınmıştır. Ayrıca hemşirelere araştırmaya katılmaları durumunda verdikleri bilgilerin gizli tutula-cağı ve sadece bu araştırmada kullanılacağ belirtilerek "gizlilik ve gizliliğin korunması" ilkesine özen gösterilmiştir.

\section{Araştırmanın Genellenebilirliği}

Araştırma verileri, Van ilinde bulunan dört hastanede çalışan hemşirelerden elde edildiği için araştırma bulguları, bu araştırma kapsamındaki hemşirelerle sınırlıdır, genellenemez. 


\section{Bulgular}

Hemşirelerin \%63.3'ünün kadın, \%46.0'sının 2633 yaş aralığında, \%49.2'sinin lisans mezunu, $\% 50.7$ 'sinin evli olduğu, \%58.1'inin çocuk sahibi olmadığı, \%41.2'sinin 2 çocuk sahibi olduğu ve \%33.1'inin gelir durumunun kısmen yeterli olduğu saptanmıştır (Tablo 1).

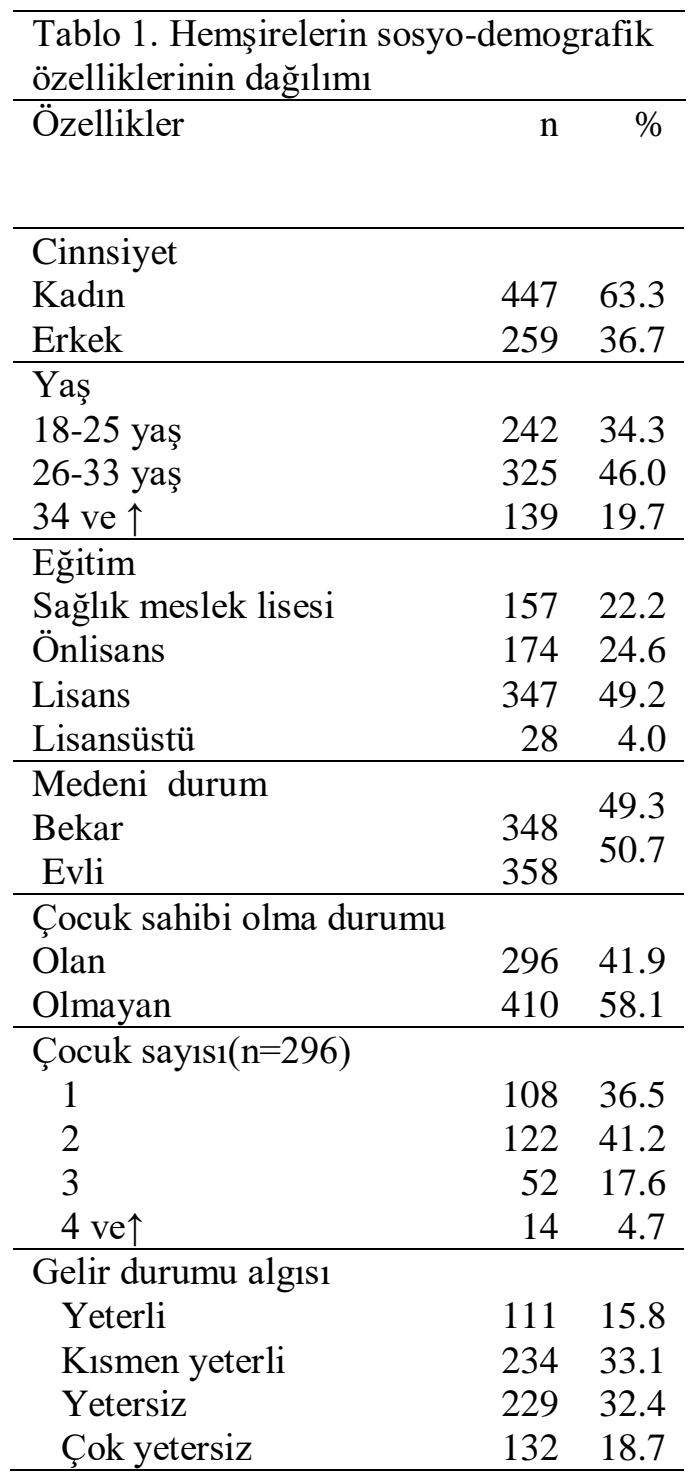

Hemşirelerin \% 50.7'sinin Van Bölge Eğitim ve Araştırma Hastanesi, \%35.3'ünün Yüzüncü Y11 Üniversitesi Dursun Odabaşı Tıp Merkezi, \%12.6'sının İpekyolu Devlet Hastanesi, \%1.4'ünün Van Ağız ve Diş Sağlığı Merkezi'nde çalıştığ belirlenmiştir (Tablo 2).
Tablo 2. Hemşirelerin mesleki özelliklerinin dağılım

\begin{tabular}{|c|c|c|}
\hline Özellikler & $\mathrm{n}$ & $\%$ \\
\hline \multicolumn{3}{|l|}{ Toplam çalışma yılı } \\
\hline $1-5$ y1l & 375 & 53.1 \\
\hline $6-10 \mathrm{yll}$ & 217 & 30.8 \\
\hline $11-15$ yll & 65 & 9.2 \\
\hline 16 yll ve $\uparrow$ & 49 & 6.9 \\
\hline \multicolumn{3}{|l|}{ Çalışılan birim } \\
\hline Cerrahi birimler & 137 & 19.4 \\
\hline Dahili birimler & 112 & 15.9 \\
\hline Çocuk & 123 & 17.4 \\
\hline Yoğun bakım & 135 & 19.1 \\
\hline Diş & 10 & 1.4 \\
\hline Poliklinik & 189 & 26.8 \\
\hline \multicolumn{3}{|l|}{ Çalışılan pozisyon } \\
\hline Hemşirelik Hizmetleri & 4 & 0.6 \\
\hline Müdürü & 12 & 1.7 \\
\hline Hemşirelik Hizmetleri & 17 & 2.4 \\
\hline Müdür Yardımcısı & 70 & 9.9 \\
\hline Klinik Başhemşiresi & 603 & 85.4 \\
\hline Klinik Sorumlu Hemşiresi & & \\
\hline Klinik hemşiresi & & \\
\hline \multicolumn{3}{|l|}{ Çalışma süresi } \\
\hline $1-5$ y1l & 504 & 71.4 \\
\hline 6-10 yil & 156 & 22.1 \\
\hline $11-15$ y1l & 35 & 5.0 \\
\hline 16 yil ve $\uparrow$ & 11 & 1.5 \\
\hline \multicolumn{3}{|l|}{ İş yükü/günlük } \\
\hline Çok Fazla & 247 & 35.0 \\
\hline Fazla & 280 & 39.7 \\
\hline Normal & 155 & 22.0 \\
\hline $\mathrm{Az}$ & 10 & 1.3 \\
\hline Çok az & 14 & 2.0 \\
\hline \multicolumn{3}{|l|}{ Mesleği sevme derecesi } \\
\hline Çok seviyor & 72 & 10.2 \\
\hline Seviyor & 243 & 34.4 \\
\hline Kararsız & 83 & 11.8 \\
\hline Sevmiyor & 207 & 29.3 \\
\hline Hiç sevmiyor & 101 & 14.3 \\
\hline \multicolumn{3}{|l|}{ Beklentilerini karşılama durumu } \\
\hline Çok karşı1lyor & 11 & 1.5 \\
\hline Karşıliyor & 134 & 19.0 \\
\hline Kararsiz & 128 & 18.1 \\
\hline Karşılamıyor & 302 & 42.8 \\
\hline Hiç karşılamıyor & 131 & 18.6 \\
\hline \multicolumn{3}{|l|}{$\begin{array}{l}\text { Kurumda duygu ve düşüncelerin } \\
\text { dikkate alınma derecesi }\end{array}$} \\
\hline Çok dikkate alınıyor & 19 & 2.7 \\
\hline Dikkate alınıyor & 157 & 22.2 \\
\hline Kararsızım & 116 & 16.5 \\
\hline Dikkate alınmıyor & 250 & 35.4 \\
\hline Hiç dikkate alınmıyor & 164 & 23.2 \\
\hline
\end{tabular}


Hemşirelerin \%53.1'inin toplam çalışma süresinin olduğu saptanmıştır. Hemşirelerin \%19.4'ünün cerrahi, \%19.1'inin yoğun bakım birimlerinde, \%71.4'ünün 1-5 yıl süredir şu an çalıştığ1 birimde görev yaptığ1 saptanmıştır. Hemşirelerin \%35.0'i günlük iş yükünün çok fazla, \%39.7'si fazla, olduğunu ve hemşirelerin \%34.4'ü mesleği sevdiği, \%42.8'i kurumun çalışma ortamı beklentilerini karşılamadığını, \%35.4'ü çalış1lan kurumda duygu ve düşüncelerin dikkate alınmadığını, belirtmiştir (Tablo 3).

TPİÖ'nden alınan min-max puanlar ve puan ortalamalarının dağılımı incelendiğinde özerklik ihtiyacı alt boyutundan en düşük 8 en yüksek 35 , yeterlilik ihtiyaci alt boyutundan en düşük 7 en yüksek 30, ilişki ihtiyacı alt boyutundan en düşük 15 en yüksek 37 ve toplamda en düşük 39 en yüksek 99 puan alındığ 1 belirlenirken, hemșirelerin özerklik ihtiyacı alt boyutundan 22.61 \pm 4.58 , yeterlilik ihtiyac1 alt boyutundan 19.91 \pm 3.13 , ilişki ihtiyacı alt boyutundan $27.43 \pm 3.95$ puan aldığ 1 ve toplam puan ortalamasının ise $69.61 \pm 8.84$ olduğu saptanmıştır (Tablo 4).

Hemşirelerin cinsiyet durumları ile yeterlilik alt boyut puan ortalaması arasındaki farkın istatistiksel olarak anlamlı olduğu belirlenmiştir $(\mathrm{p}<0.05)$.

Tablo 3. TPİÖ'den Puan Ortalamalarının

Dağglımı

\begin{tabular}{lcc}
\hline Alt Boyutları & Min-Max & $\bar{X}_{ \pm S S}$ \\
\hline $\begin{array}{l}\text { Özerklik } \\
\text { ihtiyac1 }\end{array}$ & $8-35$ & $22.61 \pm 4.58$ \\
\hline $\begin{array}{l}\text { Yeterlilik } \\
\text { ihtiyac1 }\end{array}$ & $7-30$ & $19.91 \pm 3.13$ \\
\hline $\begin{array}{l}\text { İlişki (aidiyet) } \\
\text { ihtiyac1 }\end{array}$ & $15-7$ & $27.43 \pm 3.95$ \\
\hline Toplam Puan & $39-9$ & $69.61 \pm 8.84$ \\
\hline
\end{tabular}

Hemşirelerin sosyo-demografik özelliklerine göre TPİÖ puanları karşılaştırıldığında kadın hemşirelerin özerklik $(27.19 \pm 3.79)$, yeterlilik (20.15 \pm 3.06$)$, ilişki $(27.57 \pm 3.92)$ alt boyutu ve toplam puan ortalamasinın $(70.00 \pm 8.82)$ erkek hemşirelerden daha yüksek olduğu belirlenmiştir (Tablo 4).

Hemşirelerin yaş grubu, eğitim durumu, medeni durum, çocuk sahibi olma durumu, çocuk sayısı ve gelir durumuna göre ölçek alt boyut puan ortalamaları ve toplam puan ortalaması arasındaki farkın istatistiksel olarak anlamlı olmadığ 1 saptanmıştır $(\mathrm{p}>0.05)$. 18-25 yaş grubundaki hemşirelerin özerklik (27.26 \pm 3.85$)$, yeterlilik $(20.08 \pm 3.20)$, ilişki $(27.59 \pm 3.92)$ toplam puan ortalamasının $(70.04 \pm 9.21)$ diğer yaş gruplarına göre daha yüksek olduğu, lisansüstü öğrenim mezunu hemşirelerin özerklik (22.82 \pm 5.68$)$, yeterlilik $(20.75 \pm 2.82)$ puan ortalamas1 ve toplam puan ortalamasinın $(70.07 \pm 9.39)$, lisans mezunu hemşirelerin ilişki $(27.63 \pm 3.90)$ puan ortalamasının diğer gruplara göre daha yüksek olduğu, bekar hemşirelerin özerklik (27.63 \pm 3.74$)$, yeterlilik (20.00 \pm 3.23$)$, ilişki (27.63 \pm 3.74$)$ toplam puan ortalamasının (70.20 \pm 8.92$)$ evli hemşirelere göre daha yüksek olduğu, çocuk sahibi olmayan hemşirelerin özerklik (22.85 \pm 4.80$)$, yeterlilik (19.98 \pm 3.20$)$, ilişki $(27.57 \pm 3.77)$ toplam puan ortalamasının $(70.03 \pm 9.03)$ çocuk sahibi olan hemşirelere göre daha yüksek olduğu dört veya daha fazla sayıda çocuk sahibi olan hemşirelerin, özerklik (23.21 \pm 4.45$)$ puan ortalamasının daha yüksek olduğu saptanırken, iki çocuk sahibi olan hemşirelerin yeterlilik (20.05 \pm 2.92$)$, ilişki (27.39$\pm 4.06)$ toplam puan ortalamasinın $(69.56 \pm 8.85)$ diğer gruplara göre daha yüksek olduğu gelir durumunun yeterli olduğunu ifade eden hemşirelerin özerklik (23.83 \pm 4.07$)$, ilişki (28.02$\pm 4.86)$ toplam puan ortalamasinın $(71.73 \pm 9.63)$ kısmen yeterli olduğunu ifade eden hemşirelerin yeterlilik $(20.23 \pm 2.89)$, alt boyutu puan ortalamasının diğer gruplara göre daha yüksek olduğu saptanmıştır (Tablo 5).

Hemşirelerin çalıştı̆g 1 hastane ile özerklik alt boyut puan ortalaması arasındaki farkın istatistiksel olarak anlamlı olduğu saptanmıştır $(\mathrm{p}<0.05)$. Hemşirelerin mesleki özelliklerine göre TPİÖ puan ortalamalarıyla karşılaştırılmaları tablo 5 'de görülmektedir.

Hemşirelerin meslekte toplam çalışma süresi, çalıştığı klinikler, çalışma pozisyonları, çalışmakta olduğu birimde çalışma süreleri, günlük iş yükü durumları, hemşirelerin mesleğini sevme durumları, kurumun beklentilerini karşılama durumları ve çalıştıkları kurumda duygu ve düşüncelerinin dikkate alınma durumları ile temel psikolojik ihtiyaç ölçeği puanları arasında istatistiksel olarak anlamlı fark olduğu belirlenmiştir. 


\begin{tabular}{|c|c|c|c|c|}
\hline \multirow{3}{*}{ Özellikler } & \multicolumn{3}{|c|}{ ALT BOYUTLAR } & \multirow{3}{*}{$\begin{array}{l}\text { Toplam puan } \\
\bar{X}_{ \pm \mathrm{SS}}\end{array}$} \\
\hline & Özerklik & Yeterlilik & İlişki & \\
\hline & $\bar{X}_{ \pm \mathrm{SS}}$ & $\bar{X}_{ \pm \mathrm{SS}}$ & $\bar{X}_{ \pm \mathrm{SS}}$ & \\
\hline \multicolumn{5}{|l|}{ Cinsiyet } \\
\hline Kadın & $27.19 \pm 3.79$ & $20.15 \pm 3.06$ & $27.57 \pm 3.92$ & $70.00 \pm 8.82$ \\
\hline Erkek & $26.91 \pm 3.87$ & $19.51 \pm 3.22$ & $27.18 \pm 3.99$ & $68.94 \pm 8.87$ \\
\hline Test ve $\mathrm{p}$ değeri & $\mathrm{t}=0.94, \mathrm{p}>0.05$ & $\mathrm{t}=2.62, \mathrm{p}<0.05$ & $\mathrm{t}=1.28, \mathrm{p}>0.05$ & $\mathrm{t}=1.54, \mathrm{p}>0.05$ \\
\hline \multicolumn{5}{|l|}{ Yaş } \\
\hline $18-25$ yaş & $27.26 \pm 3.85$ & $20.08 \pm 3.20$ & $27.59 \pm 3.92$ & $70.04 \pm 9.21$ \\
\hline $26-33$ yaş & $27.14 \pm 3.70$ & $19.81 \pm 3.02$ & $27.51 \pm 3.88$ & $69.83 \pm 8.41$ \\
\hline 34 ve $\uparrow$ & $26.65 \pm 4.03$ & $19.87 \pm 3.30$ & $26.94 \pm 4.14$ & $68.36 \pm 9.13$ \\
\hline Test ve $\mathrm{p}$ değeri & $\mathrm{f}=1.19, \mathrm{p}>0.05$ & $\mathrm{f}=0.54, \mathrm{p}>0.05$ & $\mathrm{f}=1.35, \mathrm{p}>0.05$ & $f=1.77, p>0.05$ \\
\hline \multicolumn{5}{|l|}{ Eğitim } \\
\hline Sğlk. Mes. Lis. & $22.44 \pm 5.11$ & $19.92 \pm 3.17$ & $27.59 \pm 3.97$ & $69.74 \pm 9.88$ \\
\hline Önlisans & $22.38 \pm 4.57$ & $20.19 \pm 3.18$ & $26.97 \pm 4.01$ & $69.33 \pm 8.46$ \\
\hline Lisans & $22.78 \pm 4.24$ & $19.71 \pm 3.11$ & $27.63 \pm 3.90$ & $69.66 \pm 8.52$ \\
\hline Lisansüstü & $22.82 \pm 5.68$ & $20.75 \pm 2.82$ & $26.82 \pm 3.96$ & $70.07 \pm 9.39$ \\
\hline Test ve $\mathrm{p}$ değeri & $\mathrm{KW}=0.38, \mathrm{p}>0.05$ & $\mathrm{KW}=6.41, \mathrm{p}>0.05$ & $\mathrm{KW}=3.95, \mathrm{p}>0.05$ & $\mathrm{KW}=0.34, \mathrm{p}>0.05$ \\
\hline \multicolumn{5}{|l|}{ Medeni durum } \\
\hline Bekar & $27.63 \pm 3.74$ & $20.00 \pm 3.23$ & $27.63 \pm 3.74$ & $70.20 \pm 8.92$ \\
\hline Evli & $27.23 \pm 4.13$ & $19.83 \pm 3.04$ & $27.23 \pm 4.13$ & $69.04 \pm 8.75$ \\
\hline Test ve $\mathrm{p}$ değeri & $\mathrm{t}=1.36, \mathrm{p}>0.05$ & $\mathrm{t}=0.72, \mathrm{p}>0.05$ & $\mathrm{t}=1.36, \mathrm{p}>0.05$ & $\mathrm{t}=1.75, \mathrm{p}>0.05$ \\
\hline \multicolumn{5}{|c|}{ Çocuk sahibi olma durumu } \\
\hline Olan & $22.27 \pm 4.25$ & $19.82 \pm 3.05$ & $27.23 \pm 4.18$ & $69.04 \pm 8.56$ \\
\hline Olmayan & $22.85 \pm 4.80$ & $19.98 \pm 3.20$ & $27.57 \pm 3.77$ & $70.03 \pm 9.03$ \\
\hline Test ve $\mathrm{p}$ değeri & $\mathrm{t}=1.13, \mathrm{p}>0.05$ & $\mathrm{t}=1.67, \mathrm{p}>0.05$ & $\mathrm{t}=0.68, \mathrm{p}>0.05$ & $\mathrm{t}=1.47, \mathrm{p}>0.05$ \\
\hline \multicolumn{5}{|c|}{ Çocuk sayısı(n=296) } \\
\hline 1 & $22.60 \pm 3.87$ & $20.05 \pm 2.95$ & $27.13 \pm 4.19$ & $69.56 \pm 8.06$ \\
\hline 2 & $22.39 \pm 4.35$ & $20.03 \pm 2.92$ & $27.39 \pm 4.06$ & $69.50 \pm 8.85$ \\
\hline 3 & $21.03 \pm 4.59$ & $19.32 \pm 3.45$ & $27.05 \pm 4.29$ & $67.00 \pm 8.66$ \\
\hline $4 \mathrm{ve} \uparrow$ & $23.21 \pm 4.45$ & $18.07 \pm 2.81$ & $27.21 \pm 5.08$ & $68.50 \pm 9.20$ \\
\hline Test ve $\mathrm{p}$ değeri & $K W=5.87, p>0.05$ & $\mathrm{KW}=6.65, \mathrm{p}>0.05$ & $\mathrm{KW}=0.23, \mathrm{p}>0.05$ & $\mathrm{KW}=3.88, \mathrm{p}>0.05$ \\
\hline \multicolumn{5}{|c|}{ Gelir durumu alg1s1 } \\
\hline Yeterli & $23.83 \pm 4.07$ & $20.21 \pm 3.15$ & $28.02 \pm 4.86$ & $71.03 \pm 9.63$ \\
\hline Kısmen yeterli & $23.22 \pm 4.32$ & $20.23 \pm 2.89$ & $27.56 \pm 3.65$ & $70.68 \pm 8.09$ \\
\hline Yetersiz & $22.24 \pm 4.54$ & $19.59 \pm 3.24$ & $27.25 \pm 3.78$ & $68.86 \pm 8.69$ \\
\hline Çok yetersiz & $21.11 \pm 5.05$ & $19.67 \pm 3.30$ & $27.00 \pm 3.84$ & $67.42 \pm 9.19$ \\
\hline Test ve $\mathrm{p}$ değeri & $f=9.55, p<0.05$ & $\mathrm{f}=2.22, \mathrm{p}>0.05$ & $f=1.60, p>0.05$ & $f=6.26, p<0.05$ \\
\hline
\end{tabular}


Tablo 5. Hemşirelerin mesleki özelliklerinin TPIÖ puan ortalamalarıyla karşılaştırılması

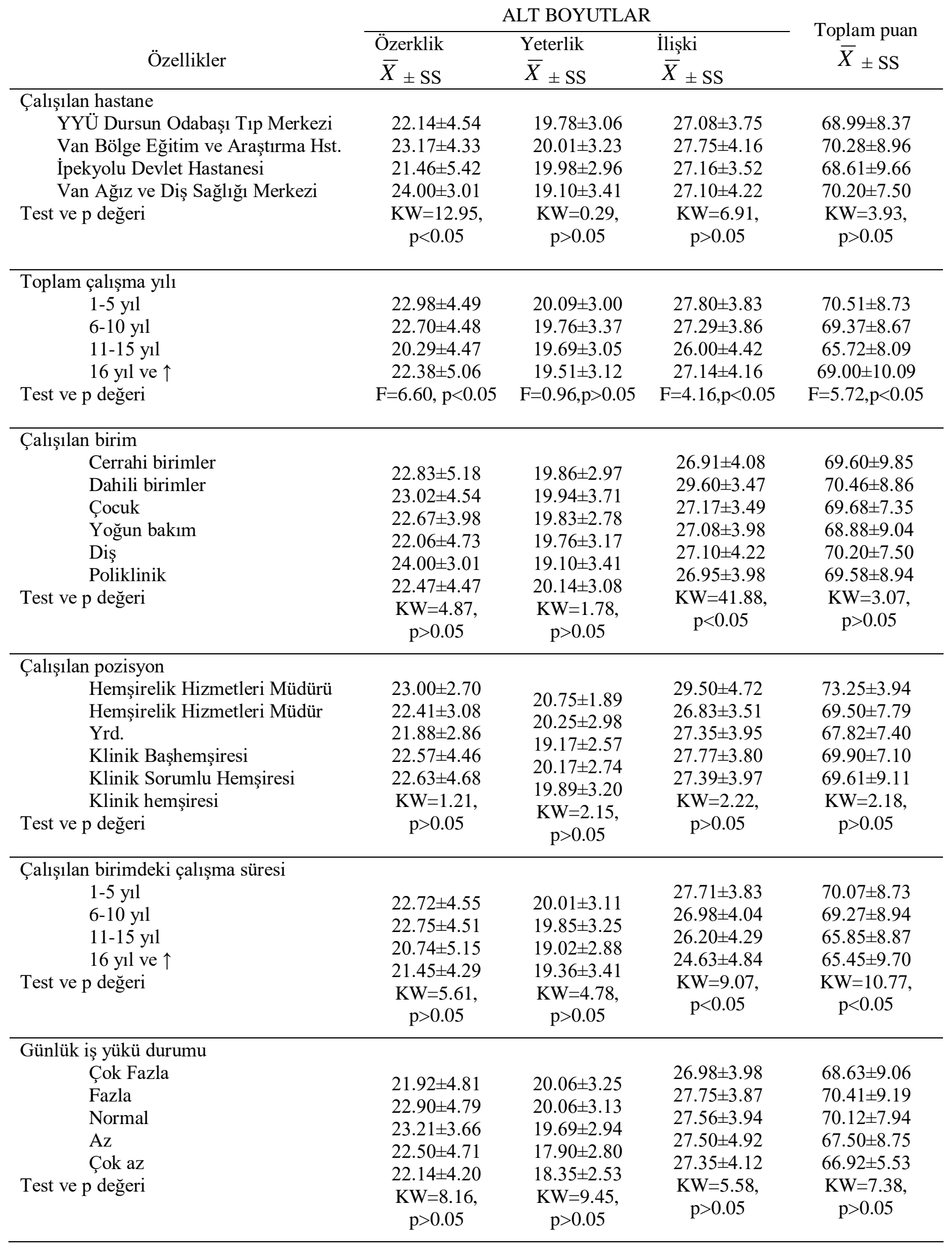


Tablo 5. Hemşirelerin mesleki özelliklerinin TPIÖÖ puan ortalamalarıyla karşılaştııılması (devamı)

\begin{tabular}{|c|c|c|c|c|}
\hline \multirow{2}{*}{ Özellikler } & \multicolumn{3}{|c|}{ ALT BOYUTLAR } & \multirow{2}{*}{$\begin{array}{l}\text { Toplam puan } \\
\bar{X}_{ \pm \mathrm{SS}}\end{array}$} \\
\hline & $\begin{array}{l}\text { Özerklik } \\
\bar{X}_{ \pm \mathrm{SS}}\end{array}$ & $\begin{array}{l}\text { Yeterlik } \\
\bar{X} \pm \mathrm{SS}\end{array}$ & $\begin{array}{l}\bar{X}_{ \pm}^{\text {İlişki }} \\
\pm \mathrm{SS}\end{array}$ & \\
\hline \multicolumn{5}{|c|}{$\begin{array}{l}\text { Kurumun beklentilerini karşılama durumu } \\
\text { Çok karşllıyor }\end{array}$} \\
\hline Karșilıyor & $26.18 \pm 4.21$ & $21.09 \pm 3.67$ & $27.18 \pm 4.68$ & $73.90 \pm 11.57$ \\
\hline Kararsiz & $23.45 \pm 3.98$ & $20.14 \pm 3.14$ & $27.85 \pm 4.37$ & $71.10 \pm 8.75$ \\
\hline Karşılamıyor & $22.73 \pm 4.56$ & $20.34 \pm 2.94$ & $27.81 \pm 3.67$ & $70.49 \pm 8.62$ \\
\hline Hiç karşılamıyor & $22.50 \pm 4.46$ & $19.80 \pm 3.01$ & $27.23 \pm 3.79$ & $69.26 \pm 8.45$ \\
\hline \multirow[t]{2}{*}{ Test ve $p$ değeri } & $21.57 \pm 5.18$ & $19.44 \pm 3.47$ & $27.09 \pm 4.03$ & $67.70 \pm 9.42$ \\
\hline & $\begin{aligned} \mathrm{KW} & =16.94 \\
\mathrm{p} & >0.05\end{aligned}$ & $\begin{array}{c}\mathrm{KW}=6.14 \\
\mathrm{p}>0.05\end{array}$ & $\begin{aligned} \mathrm{KW} & =4.92 \\
\mathrm{p} & >0.05\end{aligned}$ & $\begin{array}{c}\mathrm{KW}=13.74 \\
\mathrm{p}<0.05\end{array}$ \\
\hline \multicolumn{5}{|c|}{$\begin{array}{l}\text { Çalışllan kurumda duygu ve düşüncelerin } \\
\text { dikkate alınma durumu }\end{array}$} \\
\hline Çok dikkate alınıyor & $23.42 \pm 3.90$ & $19.42 \pm 2.83$ & $27.63 \pm 5.16$ & $70.26 \pm 9.05$ \\
\hline Dikkate alınıyor & $23.26 \pm 4.12$ & $20.22 \pm 3.25$ & $28.17 \pm 4.05$ & $71.21 \pm 8.46$ \\
\hline Kararsızım & $22.87 \pm 4.13$ & $19.97 \pm 2.93$ & $27.68 \pm 3.85$ & $70.02 \pm 8.28$ \\
\hline Dikkate alınmiyor & $22.63 \pm 4.75$ & $19.88 \pm 3.03$ & $27.04 \pm 3.73$ & $69.42 \pm 8.99$ \\
\hline Hiç dikkate alınmıyor & $21.67 \pm 5.00$ & $19.69 \pm 3.35$ & $27.10 \pm 4.02$ & $68.03 \pm 9.15$ \\
\hline Test ve $p$ değeri & $\begin{array}{l}\mathrm{KW}=8.70 \\
\mathrm{p}>0.05\end{array}$ & $\begin{array}{c}\mathrm{KW}=4.41 \\
\mathrm{p}>0.05\end{array}$ & $\begin{array}{c}\mathrm{KW}=11.54 \\
\mathrm{p}<0.05\end{array}$ & $\begin{array}{c}\mathrm{KW}=12.16 \\
\mathrm{p}<0.05\end{array}$ \\
\hline
\end{tabular}

Meslekte toplam çalışma süresinin ve kurumda kabul gördüğünü düşünen hemşirelerin TPİÖ alt boyutlarından yeterlilik, ilişki ve özerklik puan ortalamalarının daha yüksek olduğu bulunmuştur. (Tablo 3)

\section{Tartışma}

Araştırmada hemşirelerin sosyo-demografik özellikleri incelendiğinde, hemşirelerin çoğunun kadın ve evli olduğu, büyük çoğunluğunun lisans mezunu olduğu ve gelir durumunun kısmen yeterli olduğu saptanmıştır. Çalışma sürelerinin değişkenlik gösterdiği, farklı birimlerde ve farkl1 pozisyonlarda çalıştıkları belirlenmiştir. Türk'ün (23) Doğan ve Eryılmaz'ın (24) tüm akademisyenleri değerlendirdikleri çalışmada TPİÖ ölçek alt boyutlarının ve toplam puan ortalamalarının yüksek düzeyde olduğu belirtilmiştir. Bu sonuçlar araştırma bulguları ile paralellik göstermektedir.

Araştırmada erkek hemşirelerin, kadın hemşirelere göre yeterlilik ihtiyacının düşük olduğu görülmüştür. $\mathrm{Bu}$ araştırmada; temel psikolojik ihtiyaçların yeterlilik boyutunda kadın ve erkek arasındaki anlamlı farklılığın, cinsiyetler arasındaki farklı tutum ve davranışlardan kaynaklandığı düşünülebilir.
Araştırmaya katılan hemşirelerin yaş gruplarına göre puan ortalamaları değerlendirildiğinde; 18-25 yaş grubundaki hemşirelerin özerklik, yeterlilik, ilişki alt boyutu ve toplam puan ortalamasının, diğer yaş gruplarına göre daha yüksek olduğu fakat bu farklılığın anlamlı olmadığ 1 tespit edilmiştir. Türk (23)'ün, çalışmasında yaș değişkeni bakımından, akademisyenlerin özerklik, yeterlilik ve ilişki değişkenleri arasında anlamlı bir farklılık bulunmadığını belirtmiştir. Bayraktar'ın (25) hakemlerde, Annaberdiyev'in (26) öğrencilerde yaptığı çalışma bulgularıyla bu araştırma sonuçları paralellik göstermektedir.

$\mathrm{Bu}$ araştırmada hemşirelerin eğitim durumlarına göre; özerklik, yeterlilik, ilişki alt boyutu ve toplam puan ortalamasinın anlamlı olmadığ 1 belirlenmiştir. Türk'ün (23) yaptığı çalışmada akademisyenlerin öğrenim durumu değişkenine göre temel psikolojik ihtiyaçlardan özerklik, yeterlilik, ilişki arasında anlamlı bir farklılık bulunmadığını belirtmiştir. Hemşirelerin medeni durumlarına göre, temel psikolojik ihtiyaç alt boyutlarından özerklik, yeterlilik ve ilişki puan ortalamaları arasinda anlamlı bir farkl11.k bulunmamıştır. Türk'ün (23) çalışmasında da, medeni duruma göre temel psikolojik ihtiyaç alt 
boyutlarından özerklik, yeterlilik ve ilişki arasında anlamlı bir farklılık bulunmadığını belirtmiştir. $\mathrm{Bu}$ çalışma bulgusu, yapılan araştırma sonuçlarıyla paralellik göstermektedir.

$\mathrm{Bu}$ araştırmada, çocuk sahibi olmayan hemşirelerin, temel psikolojik ihtiyaç alt boyutlarından özerklik, yeterlilik ve ilişki puan ortalamaları arasındaki farkın anlamlı olmadığ1 bulunmuştur. Türk'ün (23) akademisyenlerin çocuk sahibi olma durumlarına göre, temel psikolojik ihtiyaç alt boyutlarından özerklik, yeterlilik ve ilişki puan ortalaması arasında anlamlı bir farklılık olmadığını belirtmiş̧ir. $\mathrm{Bu}$ çalışma bulgusu, yapılan araştırma sonuçlarıyla paralellik göstermektedir.

Hemşirelerin gelir durumu algısına göre, temel psikolojik ihtiyaçlar alt boyutlarından özerklik alt boyutu ve toplam puan ortalamas1 arasındaki farkın anlamlı olduğu bulunmuștur. Yeterlilik ve ilişski alt boyutu arasında anlamlı fark bulunmamıştır. Türk'ün (23) çalışmasında akademisyenlerin gelir düzeyi değişkenine göre temel psikolojik ihtiyaç alt boyutlarından, yeterlilik alt boyutu ve ilişki puan ortalaması arasında anlamlı bir farkl1lık bulunmazken özerklik alt boyutu puan ortalaması arasında anlamlı bir farklılık bulunduğu belirtilmiştir. Bu çalışma bulgusu, yapılan araştırma sonuçlarıyla paralellik göstermektedir.

Hemşirelerin çalıştıkları hastane ile özerklik alt boyut puan ortalaması arasındaki farkın istatistiksel olarak anlamlı olduğu ve yeterlik, ilişki alt boyut puan ortalamaları ve toplam puan ortalaması arasındaki farkın istatistiksel olarak anlamlı olmadığ 1 belirlenmiştir. Hemşirelerin çalıştıkları, Van Ağız ve Diş Sağlığı Merkezinde, özerklik alt boyut puan ortalamasının anlamlı olmasının, hemşire sayısının az olmasından kaynaklandığı düşünülmektedir.

Hemşirelerin toplam çalışma yılı; temel psikolojik ihtiyaçlarının alt boyutlarından özerklik ve ilişki alt boyutu ile toplam puan ortalamaları arasında anlamlı bir farklılık bulunmuş, yeterlilik puan ortalamasinda anlamlı bir farklılık bulunmamıştır. Hizmet süresi 1-5 y1l olan hemşirelerin psikolojik ihtiyaçlarındaki tatminin, çalışma yılı farklı olan diğer hemşirelere göre daha yüksek olduğu tespit edilmiştir. $\mathrm{Bu}$ durum hastanenin genç bir hemşire topluluğundan oluştuğunu göstermektedir. Aynı zamanda hizmet yılı artışı ile hemşirelerin psikolojik ihtiyaçlarının artışı arasında da doğru bir orantı olduğu düşünülebilir.
Araştırmaya katılan hemşirelerden, hemşirelik hizmetleri müdürü olarak çalışan hemşirelerin özerklik, yeterlik, ilişki alt boyutu ve toplam puan ortalamasının diğer gruplara göre daha yüksek olduğu belirlenmiştir. Türk'ün (23) , akademisyenlerin temel psikolojik ihtiyaçlarını belirlediği çalışmada, yönetimde görevli olan akademisyenlerin temel psikolojik ihtiyaçlarından özerklik ve ilişki alt boyutu puan ortalamaları arasında yönetim görevi olmayan akademisyenlere göre, anlamlı bir farkl1lik bulunduğunu belirtmiştir. Bu bulgu araştırma bulgusu ile paralellik göstermektedir. Bu bulgular doğrultusunda araştırma, iki farklı şekilde yorumlanabilir. Birincisi; bulundukları mesleki kıdemden dolayı yöneticilerin temel psikolojik ihtiyaçlarının karşılanmışlık düzeyleri yüksektir. İkincisi ise temel psikolojik ihtiyaçları karşılanmış bireyler, iş yaşamında ve kariyerlerinde başarıya ulaşabilmektedirler. ÖBK'nın temel psikolojik ihtiyaçların desteklenmesiyle bireylerin içsel motivasyonun yüksek olacağı ve öznel iyi oluş düzeyinin yüksek olacağı yönündeki açıklaması dikkate alındığında ikinci açıklamanın daha geçerli olduğu düşünülmektedir (27) Gerçekte ne olduğu ise, daha derinlemesine ve veri toplamayı gerektiren nitel desenli araştırmalarla ortaya konabilir.

Hemşirelerin çalıştıkları birimdeki çalışma süreleri; temel psikolojik ihtiyaçları alt boyutlarından özerklik ve yeterlilik alt boyutu puan ortalamaları arasında anlamlı bir farklılık göstermezken, ilişki boyutu ve toplam puan ortalamaları arasında anlamlı bir farklılık belirlenmiştir.

Hemşirelerin günlük iş yükü temel psikolojik ihtiyaçları alt boyutlarından özerklik, yeterlilik ve ilişki alt boyutu, toplam puan ortalamaları arasında anlamlı bir farklılık saptanmıştır. Bu farklılığın kurumlarda çalışan hemşirelerin \%46.0'sının 26-33 yaş aralığında olmasından kaynaklandıği düşünülmektedir.

Hemşirelerin mesleği sevmesine göre özerklik, yeterlilik, ilişki ve toplam puan ortalamaları arasında anlamlı bir farklılık saptanmıştır. Mesleği isteyerek seçmek; bireylerin mesleği severek yapmalarına, kurumu ve meslektaşlarını sevmelerine, mesleki ilişkilerinin ve iş doyumlarının yüksek olmasına dolayısıyla çalışma ortamlarını olumlu algilamalarına etki etmektedir (28) . 
Kurumun beklentileri karşılama durumuna göre, yeterlilik ve ilişki puan ortala-malarında farkın anlamlı olmadığı, özerklik alt boyutu ve toplam puan ortalamaları arasinda anlamlı bir farkl1lık olduğu saptanmıştır.

Çalıştığı kurumda duygu ve düşüncelerinin dikkatte alma durumu, özerklik, yeterlilik alt boyutları puan ortalamaları arasinda anlamlı bir farklılık belirlenmemiş, ilişki alt boyutu ve toplam puan ortalamaları arasında anlamlı bir farklılık belirlenmiştir. Sağlık çalışanları sürekli bir etkileşim içerisindedir. İlişki ihtiyacı alt boyutunun anlamlı olması, çalışılan kurumun, hemşirelerin duygu ve düşüncelerini dikkate aldığını düşündürmektedir.

\section{Sonuç ve Öneriler}

Çalışmadan ulaşılan bulgular bütünsel olarak değerlendirildiğinde, temel psikolojik ihtiyaçların doyumunun motivasyonu artırıc1, kaygıyı azaltıcı etkisi olduğu söylenebilir. Hemşirelerin de temel psikolojik ihtiyaçları ve etkileyen faktörlerin belirlenmesi amacıyla yapılan araştırmada aşağıdaki sonuçlar elde edilmiştir.

- Araştırmaya katılan hemşirelerin genel olarak servis hemşiresi olduğu, 33 yaşın altında, lisans eğitimine sahip, bayan ve evli oldukları ve hemşirelik mesleğini sevdikleri,

- Hemşirelerin temel psikolojik ihtiyaçları alt boyutlarında özerklik ihtiyacı, yeterlik ihtiyacı ve ilişki ihtiyaçlarının olduğu belirlenmiştir.

$\mathrm{Bu}$ sonuçlar doğrultusunda;

- Hemşirelerin, temel psikolojik ihtiyaçları öneminin vurgulandığı, eğitim programlarına katılmaları konusunda desteklenmeleri ve bu konuda farkındalık oluşması,

- Hemşireler tarafindan sosyal programların planlanması ve sosyal ortamlarda birlikteliğin sağlanmas1,

- Hemşirelerin psikolojik anlamda kendilerini değerlendirmeleri ve geliştirmeleri konusunda bilinçlendirilmeleri önerilebilir.

\section{Kaynaklar}

1. Karaöz S. Hemşirelerin politik gücü. Cumhuriyet Üniversitesi, Hemşirelik Yüksek Okulu Dergisi, Sivas, 2004, 8:30.

2. Deci E L, Vansteenkiste M. Self-determination theory and basic need satisfaction: understanding human development in positive psychology. Ricerche Di Psichologia, 2004, 27: 17-34.

3. Deci E, Connell J ve Ryan R. Selfdetermination in a Work Organization. Journal of Applied Psychology, 1989, 74: 580-590.

4. Maslow Teorisi. : Erişim Tarihi : 04.09.2014

5. Kanoğlu B. Çalışan Memnuniyeti ve Motivasyonuna Etki Eden Unsurlar: İstaç A.Ş. Örnek Uygulama. Sosyal Bilimler Enstitüsü, Çalışma Ekonomisi ve Endüstri İlişkileri Anabilim Dalı, Çalışma Ekonomisi Bilim Dalı. Yüksek Lisans Tezi, İstanbul: Marmara Üniversitesi, 2007, 23.

6. Temel Psikolojik İhtiyaçlarımız $\mathrm{Ne}$ Kadar Karşılanıyor? http://ajanspsikoloji.com/temelpsikolojik-ihtiyaclariniz-ne-kadar-karsilaniyor Erişim Tarihi: 04.06.2014.

7. Budak S. Psikoloji Sözlüğü, Ankara, Bilim ve Sanat Yayınları, 2000.

8. Deci E. L, Ryan, R. M. The 'what' and 'why' of goal pursuits: human needs and the selfdetermination of behavior. Psychological Inquiry, 2000, 11:227-268.

9. Ryan R.M, Deci E.L. Self-determination theory and the facilitation of intrinsic motivation, social development, and well-being. American Psychologist, 2000, 55; 68-78.

10.Ryan RM, Deci EL. The darker and brighter sides of human existence: Basic psychological needs as a unifying concept. Psychological Inquiry, 2000, 11: 319-338.

11.Arık A. Motivasyon ve Heyecana Giriş, 3.Bask1, İstanbul, Çantay Kitabevi, 1996:58

12.Terakye G. Hemşirelikte İletişim ve Hasta Hemşire İlişkileri, , Ankara, 1994

13.Sönmez V. Öğretmenlik Mesleğine Giriş, Ankara, Anı Yayınc1lık, 2004

14. Oflaz F. Felaketlerin psikolojik etkileri ve hemşirelik uygulaması, Cumhuriyet Üniversitesi. Hemşirelik Yüksekokulu Dergisi, Sivas, 2008, 12:1

15.Yiğit R. Konya İlinde Öğrenim gören yabanc1 uyruklu üniversite öğrencilerinin temel psikolojik ihtiyaçlarının bir kısım değişkenler bakımından incelenmesi. Selçuk Üniversitesi Sosyal Bilimler Enstitüsü Dergisi, 2012, 27: 317.

16.Çankaya CZ. Öğretmen adaylarında temel psikolojik ihtiyaçların doyumu ve iyi olma. Türk Eğitim Bilimleri Dergisi, 2009, 7: 691-71. 
17.Özaydın N. Mesleki Müzik Eğitimi Alan Öğrencilerin Psikolojik İhtiyaçlarının ve Yaşam Doyumlarının İncelenmesi. Eğitim Bilimleri Enstitüsü, Güzel Sanatlar Eğitimi Anabilim Dalı, Müzik Öğretmenliği Bilim Dalı. Yüksek Lisans Tezi, Konya: Selçuk Üniversitesi, 2011:21-23

18.Durmaz M. Ortaöğretim Öğrencilerinin (10. Sınıf) Temel Psikolojik İhtiyaçlarının Karşılanmışlık Düzeyleri, Motivasyon ve Matematik Kaygısı Arasındaki İlişkilerin Belirlenmesi. Eğitim Bilimleri Enstitüsü, İlköğretim Matematik Öğretmenliği Anabilim Dalı. Yüksek Lisans Tezi. Bolu: Abant İzzet Baysal Üniversitesi, 2012.

19.Çelikkaleli O, Gündoğdu M. Eğitim fakültesi öğrencilerinin psikolojik ihtiyaçları. İnönü Üniversitesi Eğitim Fakültesi Dergisi, Malatya, 2005, 6:43-53.

20.Gagné M. The role of autonomy support and autonomy orientation in prosocial behavior engagement. Motivation and Emotion, 2003. 27:199-223.

21.Sünbül AM, Kesici Ş, Üre Ö, Bozgeyikli H. Temel psikolojik ihtiyaçlar ölçeğinin geçerlik ve güvenirliği, VII. Ulusal PDR Kongresinde Sunulan Bildiri, Malatya, 2003.

22.Durmaz M, Akkuş R. Ortaöğretim öğrencilerinin hayallerindeki matematik bağlamında matematik algılarının, bu algıları etkileyen faktörlerin ve matematikten beklentilerinin incelenmesi. IX. Ulusal Fen
Bilimleri ve Matematik Eğitimi Kongresinde sunulan bildiri, İzmir. 2010.

23.Türk S. Akademisyenlerin Temel Psikolojik İhtiyaçlarının ve Temel Doyum Düzeylerinin Çeşitli Değişkenler Açısından İncelenmesi. Sağlık Bilimleri Enstitüsü, Psikiyatri Hemşireliği Anabilim Dalı. Yüksek Lisans Tezi, İstanbul: Marmara Üniversitesi, 2013.

24.Doğan T, Eryılmaz A. Akademisyenlerde işle ilgili temel ihtiyaç, doyumu ve öznel iyi oluş. Ege Akademik Bakış Dergisi, 2012,12:383389.

25.Bayraktar G, Kuru E. Güreş hakemlerinin temel psikolojik ihtiyaçlarının incelenmesi. Niğde üniversitesi. Beden Eğitimi ve Spor Bilimleri Dergisi, 2007, 1:27- 39.

26. Annaberdiyev D. Türkiye'de Eğitim Gören Türk Cumhuriyetleri ve Türk Üniversite Öğrencilerinin Psikolojik Yardım Arama Tutumları, Psikolojik İhtiyaçları ve Psikolojik Uyumlarının Bazı Değişkenler Açısından İncelenmesi. Sosyal Bilimler Enstitüsü, Rehberlik ve Psikolojik Danı̧̧manlık Bilim Dalı. Yüksek Lisans Tezi, Izmir: Ege Üniversitesi,2006: 26.

27.Aktepe E. Genel İşletme, Mesleki ve Teknik Yayınlar Serisi, Nobel Yayın Dağıtım, Kasım 2007,19.

28.Mollaoğlu $M$ ve ark. Hastanede çalışan hemşirelerin çalışma ortamlarına ilişkin algılarının değerlendirilmesi, Fırat Sağlık Hizmetleri Dergisi, 2010, 5:15. 